\title{
Levinas and the Poetic Word: Writing with Baudelaire?
}

\section{Introduction}

When Levinas's youth works were first published, it was a surprise to discover that he had also been a poet. The volume Eros, littérature et philosophie (Levinas 2013) includes a series of poems in Russian, written in the beginning of the 1920s, when Levinas was sixteen or seventeen. Poetry - and literature in general - was Levinas's first love, and these unpublished works show how, in his youth, he hesitated for a time between literature and philosophy. This biographical fact explains both his sensitivity to poetry and literature and his incisive comments on his favourite authors: Shakespeare, Baudelaire, Proust, Celan, Blanchot and several others. It also explains the great number of literary quotations in his philosophical works.

These literary references have been recorded with great precision, for instance in the Levinas Concordance (Ciocan \& Hansel 2005), but few commentators have studied them closely. Behind the detailed examination of these references, what is at stake is Levinas's relationship to literature, which is, at the very least, ambiguous, as many readers of Levinas know. In an earlier article, I called it the ambiguity between "aesthetical temptation" and "ethical resistance" to this temptation (Schulte Nordholt 1999). Repeatedly, Levinas insists on how poetry, with its enchanting rhythms, fascinates and carries away the artist (and the reader) to a realm where he is no longer responsible for himself; at the same time, however, he sees art, and especially poetry - or, perhaps we should say, some art, some poetry - as a language which may make an ethical relation of proximity and responsibility possible. This explains how Levinas is alternately full of admiration and full of horror for the literary work.

In Altered Reading: Levinas and Literature (1999), Jill Robbins provides a thorough examination of Levinas's relationship to literature. Like Robert Eaglestone (1997), she underlines how Levinas's positions on literature shifted over the years, from his condemnatory views in his early article "La réalité et son ombre" (Levinas 1948) to the much more positive views in his later essays on Celan and Agnon in Noms propres (Levinas 1976), where poetry seems able to realize the ethical relation to the other. Robbins pays close attention to Levinas's practice of quoting and what it means for his relationship with literature. This culminates in a perceptive interpretation of Levinas's repeated quotation of Rimbaud's famous formula "Je est un autre.” More recently, the question has been taken up by Alain Paul 
Toumayan (2009), who provides a rather swift but clear survey of Levinas's readings of nineteenth-century French literature, focusing on the Baudelaire case.

In the following, while relying on these former studies, I wish to more closely examine Levinas's reading of Baudelaire, especially in De l'existence à l'existant (Levinas 1947). ${ }^{1}$ In this early work, the network of literary quotations is markedly dense, especially in the chapter "Existence sans monde." Literary quotations form an intertextual network here and include Shakespeare, Racine, Rimbaud, Hoffmann, Huysmans, Maupassant, Valéry, and Zola. This is also where Baudelaire is most present. This seems therefore the appropriate text by which to investigate the impact of Baudelaire's poetry on Levinas's thought and writing practice. How do Levinas's quotations of Baudelaire function? Are they mere illustrations of his argument and shared cultural references? Or does Baudelaire's poetry have a different, more incisive status, determining Levinas's thought more profoundly? These questions require not just contextual reading but also an examination of how these quotations are inserted into the text. As Robbins observes, Levinas's literary quotes are mostly "covert, non-citational references to a shared literary heritage” (Robbins 1999, 90). Baudelaire is often quoted literally, but without quotation marks and without mentioning the title of the poem or reproducing the disposition of the verses. In this way, Levinas integrates verse into his prose, weaving it into his writing. In some cases, as Robbins shows, he may "overturn" or even betray what he is quoting. The real question, however, is not so much Levinas's fidelity to the literary text but what is at stake in his practice of literary texts, of Baudelaire's poems in particular. ${ }^{2}$

\section{Poetry, Totality, and Infinity}

Ah! ne jamais sortir des Nombres et des Etres! ${ }^{3}$ This final verse of "Le Gouffre" is the most frequently quoted Baudelaire line in Levinas's work, from De l'évasion to De l'existence à l'existant, Totalité et infini, and to his essays on Maurice Blanchot. Levinas rightly sees this realm of numbers and beings as an expression of what he calls the atmosphere of Being, of totality, and reads Baudelaire's exclamation as a desperate cry: "how terrible it would be never to get out of numbers and beings!" His whole philosophy, from its very start - as the title De

1 In my quotations I will use the English translation by Alphonso Linguis, published in 1978.

2 Baudelaire, Les fleurs du mal (1961). For the English quotations from Baudelaire, I will use the translation by William Aggeler, The Flowers of Evil (1954).

3 "Ah! Never to go out from Numbers and Beings!” ("The Abyss," Baudelaire 1954). 
l'évasion shows - is an attempt to escape this atmosphere, to go beyond it. In De l'évasion, he speaks of "a profound need to get out of Being" ["un besoin profound de sortir de l'être"] (Levinas 1982, 97) and to break with Heideggerian ontology. Here, Toumayan goes astray when interpreting the Baudelaire line as "the exclamation of ironic nostalgia for empiricism" (Toumayan 2009, 138). There is no irony in Levinas's quoting of this line, but the recognition of a longing for the Infinite that he shares with Baudelaire. But the question remains: may literature, poetry, be one of the ways of quitting the atmosphere of "numbers and beings"? Or are they bound with totality?

We may take this question further by examining the two poetry quotations that open and close Totalité et Infini: a Rimbaud and a Baudelaire quotation from, respectively, the incipit and excipit of the book. The first is: "'La vraie vie est absente.' Mais nous sommes au monde." "This famous phrase from Rimbaud's "Une saison en enfer" is a confession put in the mouth of Verlaine, who complains about his ruined life and says farewell to writing. But Rimbaud's original line runs slightly differently: "La vraie vie est absente. Nous ne sommes pas au monde." Levinas's quotation is thus a contrapuntal one, as if to say that Rimbaud's "real life" is but an illusion since one cannot escape the world, since we are irremediably bound to the world. But this being bound to the world enables us to feel a metaphysical longing for the infinite, for something beyond the world. This is an example showing how Levinas's quotations are certainly more than a mere illustration. ${ }^{5}$ The same goes for the last sentence of the book, where the "heroic existence" of the individual is described in Baudelaire's words as the victory of "l'ennui, fruit de la morne incuriosité qui prend les proportions de l'immortalité" (Levinas 1980, 284) - the two last lines of the second strophe of "Spleen" no. 76:

Rien n'égale en longueur les boiteuses journées

Quand sous les lourds flocons des neigeuses années

L'ennui, fruit de la morne incuriosité,

Prend les proportions de l'immortalité. ${ }^{6}$

4 "Real life is absent. But we are in the world."

5 See also the detailed analysis by Robbins of this line and of the much quoted "Je est un autre." In her diachronic reading, she comes to a different conclusion: Levinas overturns, betrays the Rimbaud line, making it express the dismissal of any ethical meaning of literature (Robbins 1999, 119-131).

6 In all quotations, the verses quoted by Levinas are in italics.

Nothing is so long as those limping days,

When under the heavy flakes of snowy years,

Ennui, the fruit of dismal apathy,

Becomes as large as immortality.

(Baudelaire 1954, v. 17-20) 
In the conclusion of Totalite et Infini, the quote is used as a last recapitulation of the opposition between totality and infinity. In his chapter on Eros, Levinas has just described fecundity: through Desire, we have reached "being for the Other" and goodness. To this being for the Other, he opposes the "isolated and heroic individual" imprisoned in his own subjectivity. For Levinas, the Baudelaire verses about ennui are the very expression of that identical I imprisoned in itself.

Baudelairian ennui (or Spleen) is not an accidental reference here. It plays a primordial role in Levinas's elaboration of being and of his conception of the self as an identity closed within itself, "condemned to being." This self and its "birth" out of the "there is" is the departure point of Levinas's reflexion. This is most clearly visible in De l'existence à l'existant, and it may account for the great density of Baudelaire quotations. Let us now see how, in this text, The Flowers of Evil accompanies the successive moments of Levinas's demonstration, from fatigue to work and from work to "the horror of the night."

\section{Fatigue and Spleen}

The first reference to Baudelaire is in the first part of De l'existence à l'existant. Here, Levinas tries to understand the relationship of the existent with his/her existence, with the mere fact of existing. This relationship is experienced in phenomena that precede reflexion, such as fatigue and laziness. To Levinas's view, fatigue is not accidental, and laziness is not a moral choice. More essentially, they are "positions taken with regard to existence" (Levinas 1978, 24). Fatigue is a "weariness [that] concerns existence itself" (Levinas 1978, 24), it is "the reminder of a commitment to existence [. . .]" (Levinas 1978, 24). This explains why Levinas sees fatigue as a refusal of that contract, as a desire to escape existence itself. It is a first sketch of evasion, but it remains aimless at first. At this point, a Baudelaire quote is inserted: "Like for Baudelaire's true travellers, it is a matter of parting for the sake of parting” (Levinas 1978, 25). This is a clear reference to "Le Voyage”:

Mais les vrais voyageurs sont ceux-là seuls qui partent

Pour partir ; cœurs légers, semblables aux ballons,

De leur fatalité jamais ils ne s'écartent,

Et, sans savoir pourquoi, disent toujours: Allons!

(“Le Voyage,” v. 17-20)

$7 \quad$ But the true voyagers are only those who leave

Just to be leaving; hearts light, like balloons,

They never turn aside from their fatality

And without knowing why they always say: "Let's go!"

(Baudelaire 1954, v. 15-18) 
The theme of the journey seems quite innocent at first view: an invitation to evasion. ${ }^{8}$ But let us remember that "Le Voyage" is the last poem of The Flowers of Evil: it closes part VI, the title of which is "La Mort." It is a huge poem of 144 verses, divided into eight parts, and begins with the nostalgic picture of the child with his atlas, dreaming about far countries:

Pour l'enfant, amoureux de cartes et d'estampes,

L’univers est égal à son vaste appétit.

$$
(\text { v. } 1-2)^{9}
$$

But "Le Voyage" is a journey denouncing all journeys - be they imaginary or real - as an illusion, since under different skies - tropical or polar - "Nous nous sommes souvent ennuyés, comme ici" (v. 60). ${ }^{10}$ Wherever we were, we were bored; we suffered ennui, in the strong, Baudelairian sense of the word, of a taedium vitae. Travelling around the world is nothing else but travelling around one's prison - to quote the words of Marguerite Yourcenar's Zeno in The Abyss ${ }^{11}$ - since it is impossible to get rid of oneself:

Le monde, monotone et petit, aujourd'hui,

Hier, demain, toujours, nous fait voir notre image :

Une oasis d'horreur dans un désert d'ennui.

$$
\text { (v. 110-112) })^{12}
$$

Travelling is an illusory evasion, since we are riveted to ourselves, imprisoned in our poor identity with ourselves: here we already find the heroic and isolated individual of which Levinas speaks in the last lines of Totality and Infinity. For Baudelaire, at the end of "Le Voyage," the only exit (but is it an exit?) is death. ${ }^{13}$ We are here at the darkest, most desperate point of The Flowers of Evil. Levinas, in his turn, will find a very different solution to the monotonous "plot" ("intrigue") of the subject: the revelation of the face of the Other, of Infinity. But on the side of Totality, he does share Baudelaire's experience of being riveted to being, and thinks the utter consequences of this in De l'existence à l'existant.

8 Toumayan sees it as “a poetic icon of evasion” (Toumayan 2009, 139).

9 "To a child who is fond of maps and engravings, / The universe is the size of his immense hunger" (Baudelaire 1954, v. 1-2)

10 "[. . .] we were often bored, as we are here." (Baudelaire 1954, v. 60)

11 "Who would be so besotted as to die without having made at least the round of this, his prison?” (Yourcenar 1976).

12 "The world, monotonous and small, today, / Yesterday, tomorrow, always, shows us our image: / An oasis of horror in a desert of ennui!” (Baudelaire 1954, v. 110-112).

13 Toumayan misses this by seeing "Le Voyage" as merely providing Levinas with "a salient poetic figure of evasion” (Toumayan 2009, 138). 
The experience of being riveted to being is the very definition of Baudelaire's Spleen or "Ennui." Originally, Spleen was a Romantic malaise, but in The Flowers of Evil it becomes the existential feeling of imprisonment in being and in a circular, irremissible temporality. The volume is constructed as a series of grandiose attempts to escape Ennui and to access another dimension, which he calls the Ideal. The Ideal takes on many different forms, from memory to sensation, eroticism, travelling, dreaming, imagination, music, painting, drunkenness (wine and "artificial paradises"), and poetry, to the infinite and finally to death. They are all manifestations of the Ideal, routes of evasion that may only offer a provisional relief. That is why the tension between Spleen and Ideal - the two terms are juxtaposed in the title of the first part of the volume - will never be resolved.

In the Levinas passage on laziness, the reference to Baudelaire's "Voyage" is therefore less banal than it seems at first sight. In the same passage, he states clearly that "in weariness, we want to escape from existence itself [...]" (Levinas 1978, 25). That is exactly what Baudelaire does at the end of The Flowers of Evil: to abdicate existence.

\section{From Fatigue to Work}

In the next chapter of De l'existence à l'existant, "Fatigue and the Instant," Levinas shows how fatigue is intimately linked to its opposite, work and effort. He tries to get hold of the event of fatigue, the instant of its accomplishment, and compares fatigue to "a hand little by little letting slip what it is trying to hold on to [. . .]" (Levinas 1978, 30). Fatigue thus exists only in its relationship to effort and work. But for Levinas, work is very far from being a self-realization where the slave discovers that he is a master, as in Hegel's Phenomenology. On the contrary, work and effort "reveal a subjection which compromises our freedom. [. . . ] We are yoked to our task" (Levinas 1978, 31) This slavery is due neither to the nature of the task (which may be heavy or light) nor to the fact that work is imposed upon us. It may be freely chosen, light, and yet it is a servitude because of its relation to the instant: working is acting and acting is "[to take up] an instant as an inevitable present” (Levinas 1978, 34). In that sense, work is a yoke, a "condemnation" (Levinas 1978, 34). This present is unavoidable; therefore Levinas sees it as an "eternity." At this point, he turns to Baudelaire once more:

This is at the bottom of Baudelaire's profound meditation on skeleton's digging. Existence seems to him to be both irremediably eternal and doomed to pain: unceasingly, alas, we shall perhaps have to upturn the stony soil in some unknown land and to push at the heavy spade with our naked and bleeding foot.

(Levinas 1978, 34) 
The last three lines are a literal quotation from Baudelaire's "Le Squelette laboureur." This poem was inspired by an engraving of a skeleton ploughing the earth with a spade. One may think of Holbein's engraving “Adam Cultivating the Soil”: an image of Adam after the Fall (Fig. 1). He cultivates the earth, with Death at his side.

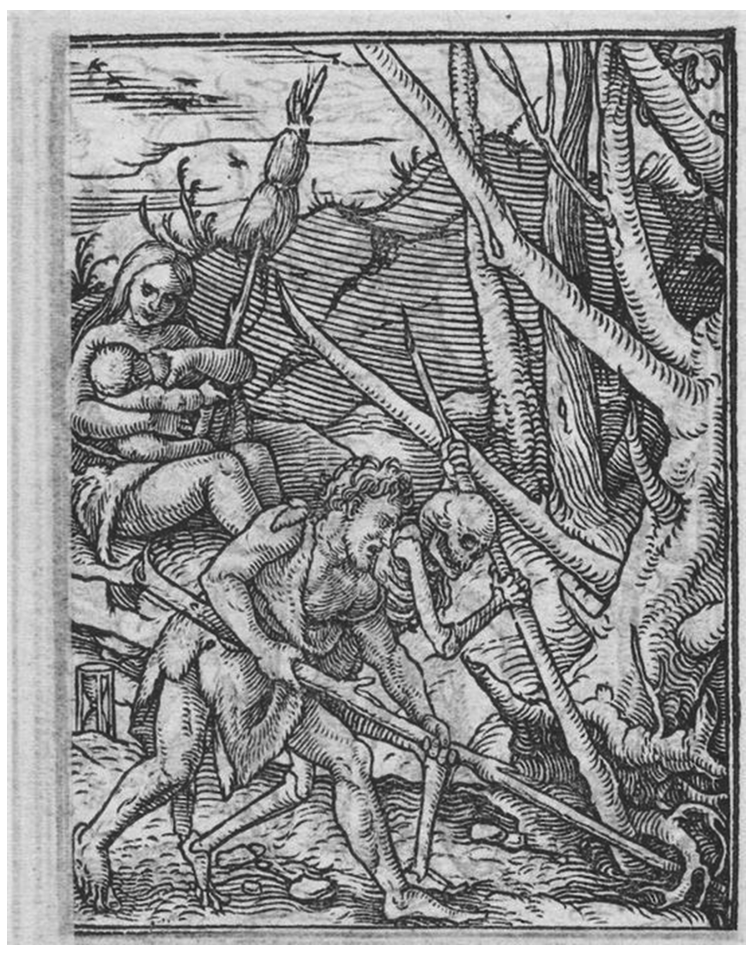

Fig. 1: Hans Holbein, "Adam Tills the Soil," woodcarving from The Dance of Death (1538), Collection of the Rijksmuseum, https://publicdomainreview.org/collections/hans-holbeinsdance-of-death-1523-5/, consulted on 12-11-19.

In the poem the lyrical I addresses the skeleton and rhetorically asks him what lesson he wants to teach mankind. Does he want to show that even death is not the end?

Qu'envers nous le Néant est traître ;

Que tout, même la Mort, nous ment ;

Et que sempiternellement,

Hélas ! il nous faudra peut-être 
Dans quelque pays inconnu

Ecorcher la terre revêche

Et pousser une lourde bêche

Sous notre pied sanglant et $n u$ ?

$$
\text { (v. 25-32) })^{14}
$$

Though he does mention Baudelaire and the title of this poem, and reproduces its literal phrasing, Levinas integrates these verses into his own text. He does not use quotation marks or italics and makes prose of it. In this way, Baudelaire's lines become an integral part of Levinas's own meditation on work and labour. It is not clear where the quotation starts or ends, unless one knows the poem quite well.

In Baudelaire, the skeleton with a spade is a cruel image of human condition after the Fall. The skeleton pictures the mortal condition of Man: while waiting to die (and to be buried in his turn), men are condemned to cultivate the soil "to the sweat of their brow," as is said in Genesis. Like Adam, men are exiled from Paradise ("in some unknown land"); they suffer and there is no end to their labour, which is subjected to time. Also, to Levinas's view, work is "an ancient curse" (Levinas 1978, 34). Man does not work in order to feed himself but the instant of the effort "condemns" him to the present, therefore to endless existence. The word "sempiternellement," counting six of the eight syllables of this line, beautifully expresses this endlessness. However, the idea of the instant also implies that the present of fatigue may be assumed by the subject. This first happens in something very simple: rest. Levinas etymologically reads the word "repos" as "re-pos": literally "the act of positing oneself on the ground" (Levinas 1978, 36). It is the first step of the "hypostasis," leading to the birth of the subject. This is where Levinas clearly leaves behind Baudelaire, for whom there is no rest, not even beyond death.

\section{5 "Silence and the Horror of Darkness"}

The following chapter of De l'existence à l'existant is about the world: the reign of all that is given, and not only as a tool for action or work. It is the world

14 "That Annihilation betrays us, / That all, and even Death, lies to us, / And that, forever and ever, / Alas! we shall be forced perhaps / In some unknown country / To scrape the hard and stony ground / And to push a heavy spade in / With our bare and bleeding feet?” (Baudelaire 1954, v. 25-32). 
where we act, walk, enjoy; in brief, it is the world where we live. This is what Levinas will later call totality. While examining this dimension, he once more takes up his favourite Baudelaire quotation from "Le Gouffre": "Western philosophy and civilisation never get out of 'numbers and beings,' remain conditioned by the secular world" (Levinas 1978, 38). Indeed, only the "sanctity" of the face of the Other may enable us to go beyond totality. But here we are already anticipating, since the word "sanctity" does not appear at this stage, where Levinas has a single aim: to get hold of the event, the birth of the subject in the anonymity of being. In order to get there, he first goes back to what lays below being: "existence without a world." He then proceeds to describe two experiences that enable us "to withdraw from the world" (Levinas 1978, 52) and confront us to the "there is" (il y a). One of them is art (painting, poetry), the other is the night.

I will not repeat here Levinas's well-known and much commented analyses of $\operatorname{art}^{15}$ : as an image distancing itself from representation, modern art "makes [things] stand out from the world" (Levinas 1978, 52), it makes them literally "exotic," by bringing them back to their original materiality, their thickness. Painting lapses into forms and colour, poetry gives priority to "the musicality of verse” (Levinas 1978, 54), that is, to prosody, rhythm and rime. Here, Levinas elaborates a theory of art but does not refer to any concrete work of art. Only in the following paragraph, the famous description of night as "the very experience of the "there is"' (Levinas 1978, 58), do we see a plethora of literary references appear, to Baudelaire and Shakespeare but also to fantastical literature. The central question is: why does night have a vaguely threatening character? Where does the instinctive fear of darkness, which is so beautifully described in fantastical tales like Hoffmann's, Poe's, or Maupassant's come from? Here is Levinas's answer:

The things of the day world then do not in the night become the source of 'the horror of darkness' because our look cannot catch them in their 'unforeseeable plots'; on the contrary, they get their fantastic character from this horror. Darkness does not only modify their contours for vision; it reduces them to undetermined, anonymous being, which sweats in them.

(Levinas 1978, 59)

The end of this passage gives the explanation: night horrifies us because in it, we sense the undetermined, anonymous, and ineluctable "there is." The key

15 See for instance Schulte Nordholt, "Tentation esthétique et exigence éthique. Lévinas et l'œuvre littéraire" (1999). 
words of this passage - "the horror of darkness" - come directly from Baudelaire, from his poem "Les Chats":

Les amoureux fervents et les savants austères

Aiment également, dans leur mûre saison,

Les chats puissants et doux, orgueil de la maison,

Qui comme eux sont frileux et comme eux sédentaires.

Amis de la science et de la volupté

Ils cherchent le silence et l'horreur des ténèbres ;

L'Erèbe les eût pris pour ses coursiers funèbres

S'ils pouvaient au servage incliner leur fierté.

$$
(\text { v. } 1-8)^{16}
$$

This admiring portrait of cats posits them as the proud companions of man but also, of course, as nocturnal, mysterious animals. Loving darkness, they are related to night and therewith to death, to the point that the god of the underworld would have liked them to help transport the dead. But this context is less important here than in the former quotations. The formula "the horror of darkness" is between quotation marks but Levinas does not give the source: it is only the formula that he finds important here. He uses it in order to underline the central thesis of this first part of De l'existence à l'existant: the disappearing of things and beings in the night (or in art) does not result in nothingness but in an "anonymous and impersonal existence," which Levinas calls "obsessive and horrible." 17 The horror of being questions Heidegger, criticizing his "Angst" in the confrontation with death. The original and strongest experience, to Levinas's view, is not the fear of nothingness but the fear of endless being, of "the impossibility of death" (Levinas 1978, 62):

We are opposing then, the horror of the night, "the silence and horror of the shades," to Heideggerian anxiety, the fear of being to the fear of nothingness. While anxiety, in Heidegger, brings about "being toward death," grasped and somehow understood, the horror of the night "with no exits" which "does not answer" is an irremissible existence. "Tomorrow, alas! one will still have to live" - a tomorrow contained in the infinity of today.

(Levinas 1978, 63)

\footnotetext{
16 "Both ardent lovers and austere scholars / Love in their mature years / The strong and gentle cats, pride of the house, / Who like them are sedentary and sensitive to cold. / Friends of learning and sensual pleasure, / They seek the silence and the horror of darkness; / Erebus would have used them as his gloomy steeds: / If their pride could let them stoop to bondage." (Baudelaire, “The Cats,” 1954, v. 1-8)

17 Preface to the second edition.
} 
Levinas repeats the quotation from "Les Chats" but adds a line from another Baudelaire poem, "Le Masque": "Demain, hélas, il faudra vivre encore!" 'Le Masque', like 'Le Squelette laboureur', is an ekphrasis of a work of art: a sculpture by Ernest Christophe representing a beautiful naked woman; she is the very expression of love but she is a misleading figure. (Fig. 2). When we look at her from a different side, we see that she wears a mask, and behind the mask she is crying. In Baudelaire's poem, the lyrical I wonders why she cries, this woman of a perfect beauty:

\begin{abstract}
Elle pleure, insensé, parce qu'elle a vécu !
Et parce qu'elle vit ! Mais ce qu'elle déplore

Surtout, ce qui la fait frémir jusqu'aux genoux,

C'est que demain hélas ! il faudra vivre encore !

Demain, après-demain et toujours - comme nous !
\end{abstract}

(v. $32-36)^{18}$

Once more, Baudelaire elaborates on the opposition between Spleen and the Ideal: perfect beauty belongs to the Ideal but it is misleading; it is just a provisional evasion from Spleen. The two-faced sculpture is an allegory of human existence as Baudelaire conceives it: a life riveted to being, "condemned" to pain and sin. In this perspective, death is seen as deliverance, as is said in the final lines of "Le Voyage.” In "Le Masque," Levinas finds the perfect expression of existence as the impossibility not to be.

Closely examining these quotations from The Flowers of evil, it seems that Baudelaire's presence in De l'existence à l'existant and in Totalité et infini is far from accidental. These quoted verses are not mere illustration of his argument but inform it, sometimes becoming an invisible intertext. Almost all of them express Baudelaire's central experience of Spleen and Ennui. This intense experience certainly played a role in shaping Levinas's first intuitions about the "there is" and the ineluctable character of being ("existence"). In that sense, Baudelaire was determining for Levinas's first philosophy, as we find it in De l'existence à l'existant. However, when Levinas describes the birth of the subject ("the hypostasis") out of existence, as he does in the second half of the essay, he turns from Baudelaire. The same goes for Totalite et infini, where the next, decisive step is taken, from the subject to the incursion of the Other. One may

18 "She is weeping, fool, because she has lived! / And because she lives! But what she deplores / Most, what makes her shudder down her knees, / Is that tomorrow, alas! she still will have to live! / Tomorrow, after tomorrow, always! - like us!” (Baudelaire, "The Mask," 1954, v. 32-36) 


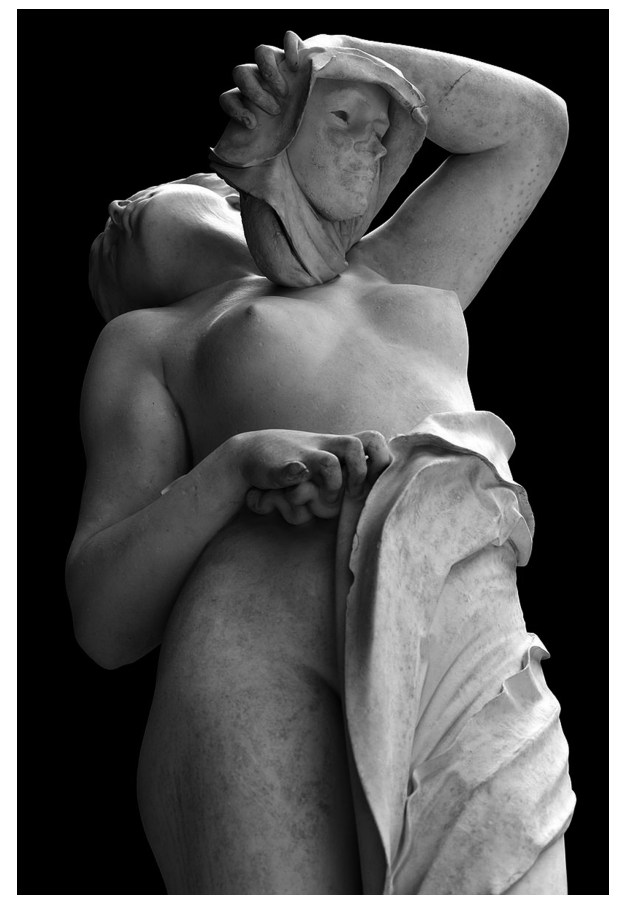

Fig. 2: Ernest Christophe, "La comédie humaine ou le Masque" (1876), Musée d’Orsay, https://en.wikipedia.org/wiki/File:The_Human_Comedy_Mask_by_Ernest_Christophe.jpg\#/ media/File:Le_Masque-Ernest_Christophe-IMG_8121-black.jpg, consulted on 14-11-19.

regret it, since many poems of The Flowers of Evil - especially those about the modern city - are about the encounter of the lyrical I with what one may call the face of the Other, in all its vulnerability: beggars, widows and orphans, blind people, old women ...

In Le temps et l'autre, when apologizing for quoting Shakespeare so often, Levinas says that "all philosophy is a mere meditation of Shakespeare" (Levinas 1979, 60). Might he have said the same about Baudelaire? We may conclude, more prudently, that Levinas's first philosophy - especially his conception of the "there is" as the impossibility of nothingness - is (amongst others) a meditation on Baudelaire's Spleen. 


\section{Bibliography}

Baudelaire, Charles. Les fleurs du mal. Paris: Classiques Garnier, 1961.

Baudelaire, Charles. The Flowers of Evil. Trans. William Aggeler. Fresno: Academy Library, 1954.

Ciocan, Christian, and Georges Hansel. Levinas Concordance. Dordrecht: Springer, 2005.

Eaglestone, Robert. Ethical Criticism: Reading After Levinas. Edinburgh: Edinburgh University Press, 1997.

Levinas, Emmanuel. “La réalité et son ombre." Les Temps Modernes 38 (1948): 769-789.

Levinas, Emmanuel. Noms propres. Montpellier: Fata Morgana, 1976.

Levinas, Emmanuel. De l'existence à l'existant. Trans. Alphonso Lingis. Dordrecht: Kluwer Academic Publishers, 1978.

Levinas, Emmanuel. Le temps et l'autre. Paris: Fata Morgana, 1979.

Levinas, Emmanuel. Totalité et infini. The Hague: Martinus Nijhoff, 1980 [1961].

Levinas, Emmanuel. De l'existence à l'existant. Paris: Vrin, 1981 [1947].

Levinas, Emmanuel. De l'évasion. Montpellier: Fata Morgana, 1982 [1935].

Levinas, Emmanuel. Essais romanesques et poétiques, notes philosophiques sur le thème d'éros. Eds. Jean-Luc Nancy and Danielle Cohen-Levinas. Paris: Grasset, 2013.

Robbins, Jill. Altered reading: Levinas and Literature. Chicago: University of Chicago Press, 1999.

Schulte Nordholt, Annelies, “Tentation esthétique et exigence éthique. Lévinas et l'œuvre littéraire.” Etudes littéraires 31.3 (1999): 69-85.

Toumayan, Alain Paul, “Levinas and French Literature." Levinas and Nineteenth-Century Literature: Ethics and Otherness from Romanticism through Realism. Eds. Donald R. Wehrs and David P. Haney. Newark: University of Delaware Press, 2009. 125-147.

Yourcenar, Marguerite. The Abyss. Trans. Grace Frick. New York: Farrar, Straus and Giroux: 1976. 
